\title{
Research on Rural Land Right Confirmation from the Perspective of Campaign-Style Governance
}

\author{
Yijia Guo \\ Beijing Normal University, Beijing, China \\ Email: guoyijia1999@163.com
}

How to cite this paper: Guo, Y.J. (2019) Research on Rural Land Right Confirmation from the Perspective of Campaign-Style Governance. Open Journal of Business and Management, 7, 1471-1484.

https://doi.org/10.4236/ojbm.2019.73101

Received: June 28, 2019

Accepted: July 23, 2019

Published: July 26, 2019

Copyright (อ 2019 by author(s) and Scientific Research Publishing Inc. This work is licensed under the Creative Commons Attribution International License (CC BY 4.0).

http://creativecommons.org/licenses/by/4.0/

\section{(c) (i) Open Access}

\begin{abstract}
This paper focuses on the implementation effect of the rural land right confirmation work carried out in China since 2013. It discusses the imbalance and good governance in the rural land right confirmation work through the review of this policy agenda. The author adopts the grounded theory research method based on interviews and literature research to find out the unbalanced points and interest conflicts of each subject in the policy agenda, focusing on Shanxi Province, which has a high proportion of traditional agriculture. This land right verification work has significant movement type governance characteristics, driven by the central, within five years to complete a nationwide land management work. Behind its high timeliness and predetermined target is a series of games from policy entrusting parties, intermediate contractors and grass-roots agents. The three forces interact and reconstruct. Task transmission becomes the main line of activities and task objectives are constantly overhead. The implementation of policy objectives is challenged. Based on this, this study proposes to improve the top-level design to avoid imbalance in sports governance. To achieve good governance through long-term planning. It provides reference for understanding the deficiency of the implementation of the policy agenda and the defect of the movement governance.
\end{abstract}

\section{Keywords}

Land Right Confirmation Movement, Campaign-Style Governance, Game Analysis

\section{Prolegomena}

The review of the policy agenda is the weak link in the existing research. Land 
right confirmation was basically completed in 2018 from 2013.

This paper chooses to carry out the survey after the implementation of the policy, which is the last and most easily overlooked link in the policy agenda cycle. This study makes up for the deficiency of the existing policy agenda evaluation, which is of great significance.

This survey is a survey on the effectiveness after the basic completion of the right confirmation, and an assessment of the final implementation effect of the land right confirmation policy. It can conduct a summative survey on whether the problems and contradictions in the policy implementation process are solved.

In the past, most investigations were conducted in the process of follow-up, and the implementation effect was often neglected, which is of profound significance for the future deepening of reform.

\section{Introduction}

1) The presentation of the question

Land is an important factor of production and a spatial carrier of human activities and social and economic development. Since the founding of the People's Republic of China in 1949, China has carried out several land reform policies, especially since the reform and opening up, China has made particularly remarkable achievements in the reform and development of the rural land system. In recent years, in order to solve the problem of unclear ownership of rural assets and chaotic management of contracted land cadastre, the state has carried out the rural land right confirmation work and completed the phased reform target in 2018, gradually establishing a complete rural asset and property rights system, invigorating rural production factors and liberating rural productive forces.

When the goal of rural land right confirmation is completed, we choose the southeast of Shanxi Province to carry out a retrospective investigation on the effect of land right confirmation to discuss the effect of policy implementation. Evaluation and investigation after policy implementation is a weak item in China's current administrative work, and "emphasis on the beginning and neglect of evaluation" is a common phenomenon in China's policy agenda. Our investigation will examine the effect and influence of such a campaign to sort out land ownership relations within a few years. Campaign governance has played an important role in rural land management over the past decades [1]. So in the land affirms authority job in recent years, is athletic type management still adapted to current reality, maintain higher management benefit? Have problems and contradictions in the implementation of policies been properly resolved? Below athletic type management, how is the result that land affirms authority to work?

2) Literature review

a) Rural land right confirmation 
Improving the agricultural production efficiency through the continuous reform of rural property rights relations is the key work in the agricultural field since China's reform and opening up, and also the necessary premise to realize the moderate scale operation of agriculture.

In recent years, the actual situation shows that vague land rights have shown a lot of inadaptability. Yu found that $73.2 \%$ of the petitioners involved in land issues, and $75.2 \%$ of the defendants were mainly grass-roots administrative departments and officials of counties and villages. In the past decade, conflicts over land have been on the rise and mass incidents have occurred frequently, which have seriously threatened social stability and farmers' vital interests [2]. Tan shukui summarized the trigger factors of farmland conflicts and found that the determination of land property rights, the exercise of land ownership, land use, land expropriation and land transfer are the fields where land conflicts occur frequently [3]. After in-depth investigation, although there are differences in the trigger factors, fighting targets and interest demands of each type of conflict, it is found that the root cause lies in vague land rights [4]. It is the defects of the system itself that lead to the dispute over the ownership of land interests, resulting in uneven distribution of interests, the infringement of vested interests and powerful groups on the weak groups, and then inter-group conflicts. Therefore, with the development of economy and society, the interests of agricultural land will gradually increase, while the vague property rights lead to the existence of a large number of "public areas". The lack of clear property rights will lead to the competitive plunder of rents in the "public domain" by various interest groups. If the clarification is not accelerated, a large number of rents will be dissipated, and more social conflicts will be caused. Therefore, the ambiguous farmland property right system has become one of the main sources of social conflicts. Therefore, it is necessary to investigate and analyze the current situation and existing problems of rural land right confirmation in China, and explore the rural land work path that conforms to China's national conditions.

b) Sport management

Movement type governance is not only the pressure type system to supply the government was forced to move, is also a lack of government social mobilization ability or face the result of rational choice, under the resources bottleneck of management objectives and management ability does not match is the sufficient condition of governance movement and its change and development has performance legitimacy logic, the ruling political logic and the logic of local autonomy and other internal logic [5]. Ouyang jing divided campaign governance into national campaign governance and grassroots campaign governance, and pointed out that, unlike national campaign governance, grassroots campaign governance is a regular administrative mechanism rather than a temporary, arbitrary and unconventional political mechanism. In practical operation, grass-roots movement governance and bureaucratic system are interdependent and interwoven, which should deal with the "central work" of grass-roots government [6]. 
From the perspective of governance benefits, campaign governance can mobilize resources, concentrate the efforts and attention of all parties to complete a specific task through top-down and political mobilization, and achieve immediate results in solving major governance problems by integrating resources and going beyond bureaucratic organizational procedures and operational norms.

Ouyang believes that since the reform and opening to the outside of the system construction process, the evolution of the land policy is the typical case of a movement type governance: the original planned economy under the governance mechanism of conventional type (namely the transfer of land supply free of charge), and the land shall not transfer to flow, completely unable to cope with changes in the reform, while the grope for establishing and perfecting new mechanism after several rounds, before and after more than 30 years [7]. Since land is one of the basic investment factors of economic growth, land policy has a great impact on economic development. And the economic transformation has brought profound changes to the use of land, an extremely large number of basic resources that spread across the country. In fact, the process of institutional construction in this field is one of the most complex and far-reaching changes in this period. Based on the above reasons, the cases in the field of land have strong representativeness in the whole reform process, and it is a good choice to discuss the role of sports governance in it.

c) Summary

From the above research, land right confirmation is a key task of rural development in China, and is faced with extremely complicated situation. Over the past decades of work practice, land work experience several big changes, constantly optimize update land ownership in land management, this study will explore a new round of approval after the change of the rural land ownership, based on the field investigation of every main body work, achieve the combination of micro and macro perspective.

From the literature, we can find that there is still a lack of retrospective research on the implementation of land policies, which is also a weak item in China's policy agenda, and insufficient attention is paid to the evaluation of the implementation of policies, especially the empirical research on the implementation of land policies. The research object of this paper is the southeast region of Shanxi Province, which has a long history of farming, villagers have a high dependence on land, and rich research resources.

\section{Review of China's Rural Land Work in the Past 70 Years}

Since the founding of the People's Republic of China, the national land policy has undergone several changes related to the vital interests of farmers, simultaneously carrying out cadastral management of rural land data and continuous reform and optimization of rural land ownership relations. In the following part, we will sort out the changes of rural land policy and the development track of relevant work since the founding of new China, and explore the inevitability and 
necessity of the land right confirmation from the perspective of history.

1) The development history of China's rural land policy

a) Land reform period: land owned by farmers, self-employed. Land reform law of the People's Republic of China

b) Socialist transformation period: land to farmers all, collective unified management. Article 17 of the model constitution of agricultural production cooperatives stipulates that "the land owned by the members must be given to agricultural production cooperatives for unified use, because the basic condition for the composition of agricultural production cooperatives is to combine the land operated by the members separately and to conduct rational and planned management".

c) People's commune period: land under collective ownership, unified management. The constitution of the People's Republic of China (1975) states that "the ownership of the means of production in the People's Republic of China at this stage mainly consists of two types: socialist ownership by the whole people and socialist collective ownership by the working people".

After the reform and opening up

Contract responsibility system: the land policy of collective ownership and household contract management. "Several problems of current rural economic policies" (1983) "joint production contract system adopts the principle of combining unified management with decentralized management, which gives full play to the collective superiority and individual initiative at the same time. The further improvement and development of this system will make the specific path of agricultural socialist cooperation more in line with the reality of our country".

Land circulation: clarify collective ownership, stabilize household contract right, and activate management right. "About perfecting the contract right of rural land property rights management division method of opinions" (2016) "stage to deepen reform of rural land system and conform to farmers' reserves the right to contract land, land circulation management, and management rights, right to contract the right to the contracted management of land is divided into the ownership, consulting and management (hereinafter referred to as the 'separation') division in parallel, promoting agricultural modernization, after the household contract responsibility system is another important system innovation in rural reform".

2) The development track of China's rural land work

a) Two rounds of land contracting work for the reform of land ownership

The first round of contracting: since 1983, the term of the contract is 15 years, and the final date is 1997.

Second round contract: from 1997, contract period 30 years, to 2028. The report of the 19th national congress of the communist party of China (CPC) proposed to "maintain a stable and long-term land contracting relationship, and extend the second round of land contracting for another 30 years after it expires". That is, where the first round of contracting expires, it should be uncon- 
ditionally extended for 30 years.

b) Land survey for land cadastral management

To make a comprehensive survey of land use, master real basic land data, establish and improve land survey, statistics and registration system, and realize socialized service of land survey information, so as to meet the needs of economic and social development and land and resources management. Rural land survey. Investigate the land type, area and ownership of land on the spot, and grasp the distribution and utilization status of all kinds of land, as well as the state of state-owned land use right and collective land ownership.

The first national land survey: began in May 1984 and ended in late 1997. "Notice of the state council approving and transferring the report of the state planning commission and other departments of the ministry of agriculture, animal husbandry and fisheries on the further investigation of land resources" (1984) "the general requirements for the detailed investigation of land resources this time are as follows: a comprehensive investigation of the type, quantity, quality, distribution and utilization status of China's land and a scientific evaluation".

The second national land survey was launched on July 1, 2007 and completed in 2009. The second national land survey of the state council on notice (2006) "the purpose is to ascertain the current status of the national land use comprehensive grasp the real land based data, establishing and perfecting the land investigation, statistics and registration system, realize land resources information socialized service, satisfy the needs of economic and social development and management of land and resources". Compared with the first national land survey, which was mainly conducted by manual survey and manual mapping, and only the area calculation was conducted by computer technology, this survey used more advanced technology and established the cadastral data system and data sharing system, which saved a lot of time.

Ten-year survey: according to article 6 of the regulations on land survey, "the state shall, in accordance with the needs of national economic and social development, conduct a national land survey every 10 years; According to the needs of land management, land change survey shall be conducted every year".

c) Land right confirmation

The no. 1 document of the central government, issued on January 31, 2013, proposes to comprehensively carry out the work of determining, registering and certifying rural land rights. Rural land right affirming is to the affirmation of land ownership, land use right and other rights. The right confirmation work started in 2013 and basically ended at the end of 2018. Meanwhile, in the process of right confirmation, cadastral data are updated through aerial photography, satellite measurement and other modern technologies, so as to realize the synchronization of land ownership management and cadastral management.

Defining the relationship of land ownership through right confirmation is conducive to rural land circulation and invigorating the rural economy, and is a 
supplement and confirmation of the past land relations. Under the situation of large-scale and market-oriented development of agriculture, right confirmation is very necessary. At the same time, it is the development direction of e-government in China in the future to renew cadastral management information and establish digital cadastral management platform through right confirmation.

\section{The Development of Rural Land Right Confirmation from the Perspective of Sports Governance}

Social governance can be divided into sports governance and institutional governance. As a means of governance corresponding to institutional governance, sports governance has been widely used in various countries in the world. In China, sports governance has always been a major governance means for the contemporary government to formulate laws and regulations, implement laws and policies and implement the ruling intention, and gradually formed a sports governance mode with Chinese characteristics, also known as Chinese sports governance. It has the authority of management main body, the specific sex of management object, the motility of management means, the short-term sex of management time, management target, the mandatory sex of management means, the high efficiency of management efficiency, the model sex of management process and so on bright feature.

China's rural land work in the long-term development, from land contracting to periodic land survey, institutional governance is its main line. In recent years, in order to solve the problem of unclear ownership relationship of rural assets and chaotic management of contracted land cadastral, China has carried out a large-scale rural land right confirmation work. This land right confirmation work has stronger characteristics of sports governance from its specific governance direction and periodic governance objectives.

Under the guidance of the no. 1 document of the central government, leading groups and offices for confirming, registering and certifying rural land contracting and management rights have been set up in all regions to pool the efforts of all departments to carry out the work. The conformity work of authority branch force is the typical way in sport management, but whether such division of labor cooperation of the department is really realized clear and efficient still needs to be discussed.

In our research area in Shanxi Province as an example, we know that cities working group mayor coalesced by the municipal government, in charge of the deputy secretary of agriculture as a deputy team leader, deputy mayor, deputy group leader, members of units including agriculture commission, bureau of finance, land and resources bureau, the municipal government legislative affairs, archives bureau, justice bureau, bureau, civil affairs bureau, forestry bureau, water department and related departments.

Under the leadership of the leading group, each member unit carries out the prescription work according to the division of responsibilities. City agriculture 
commission is responsible for the registration of the pilot work of organization and coordination, overall arrangement, the main content includes the information platform construction, organization propaganda launch, selection of surveying and mapping team, the specific operating personnel training, to develop solutions to specific problems and the rural land dispute arbitration, mediation survey published form, land contract, book printing, contracting business card printing, equaling results of inspections, etc.; The municipal bureau of finance is responsible for coordinating the implementation of funds for the confirmation, registration and certification of power, and strengthening the supervision of funds; The municipal bureau of land and resources shall be responsible for providing free control data of the results of the second national land survey or the formation of rural collective land ownership right confirmation in the process of confirming, registering and certifying the contracted management right of rural land, and providing technical guidance for surveying and mapping work; The legislative affairs office of the municipal government is responsible for participating in the research and answer of relevant policy questions in the work of power confirmation, registration and certification; The municipal archives bureau shall be responsible for guiding the archiving of documents and materials for the confirmation of rights; The municipal bureau of justice is responsible for resolving the conflicts and disputes in the confirmation of power; The municipal bureau for letters and visits shall be responsible for the handling of letters and visits in the confirmation of power; The civic bureau is responsible for providing the relevant information of the employer (village committee); The municipal forestry bureau shall be responsible for providing relevant data on the reform of forest tenure system and conversion of farmland to forests; The municipal water authority is responsible for providing small watershed management, as well as "four wasteland" and other relevant information.

Since 2013, when the no. 1 document of the central government issued the goal of land right confirmation by the end of 2018, China has carried out land right confirmation from the central government to village committees at the grassroots level. According to our investigation in Shanxi Province, as a governance activity involving multiple departments, land right confirmation often sets up special temporary leading groups at the municipal level to serve the special work, which is also a common form of temporary organization in the national administrative system. A governance movement is born for a certain project. From the division of labor and cooperation among various departments, we can see that the rural land right confirmation in Shanxi Province is the concentrated embodiment of China's campaign governance. A leading group was set up by the higher level government. All departments worked together and performed their respective duties to jointly complete the work of rural land right confirmation. In the land approval of funding problems, for example, spending a total of 50 yuan of an acre of land, the central 10 yuan, 15 yuan, the province city 15 yuan, 10 yuan region classification, ensure the smooth operation of the counterpoising 
truly work together at all levels, from the central committee and to the province, to the city, to the rural villages, top-down mobilize departments at all levels, forming a kind of efficient and accurate management mode, this is also the superiority of Chinese sport management.

However, as the definition of campaign governance indicates, such a form of governance has obvious stormy characteristics and requires all departments to work together to complete such a big task in a short time. It is a challenge for all levels of governments in terms of multi-department cooperation or coordination with the original work. In the process of investigation, we also found the emptiness and dislocation behind the efficient governance.

\section{The Game Process of Each Subject in the Rural Land Right Confirmation}

Land right confirmation works from top to bottom through the central government "subcontracting" from layer to layer, so as to induce local governments to actively participate in the implementation of their policy intentions. Similarly, local governments (such as intermediate governments such as provinces and cities) use project resources to achieve intra-territorial development goals by integrating "packaging" of various resources. Finally, the implementation of grassroots governments or economic entities (such as villages) "catch the package", that is, through actively participating in the introduction of project system to obtain resources for local development.

From the perspective of game theory, we can regard the superior government as the "principal", the intermediate government as the "contractor", and the grass-roots government or economic entity as the "agent". In other words, we can analyze the land right confirmation as a game process of principal-contractor-agent interaction.

In the survey of rural land right confirmation, we can feel the differences and contradictions in the multi-division of labor. The central government, as the entrusting party, carried out the project to clarify rural land ownership and improved a modern and clear management system. However, faced with such a huge task, local governments often have insufficient supporting facilities in terms of personnel, funds and other aspects. At the same time, the local government will continue to task under the pressure of political achievements. Finally, the village committee, as the main agent, carries out its work in the case of shortage of personnel and funds. The most convenient way is to reiterate the old records. The village committee actively cooperated with the third-party surveying and mapping company to update cadastral data according to the measurement results, but more often took out the previous files and re-signed with the villagers.

Instead of passively acting according to the intention of superiors, local governments use project resources for their own use. The pursuit of political achievements is a typical product of China's "promotion tournament" administrative 
system, in which officials try their best to make the most of their limited financial resources. Then under the land contract work, each department positively responds to participate, has formed the intricate project leading group, but in this USES its name to say the achievement, but rarely participates in the work by no means the minority. In our investigations at the grassroots level, quite a few organizational staff members under the leadership group are unaware of the existence of this task.

As the contractor, the grass-roots government constantly puts pressure on its agent, the grass-roots village committee, in order to complete the task. Under this circumstance, the interaction between the behavioral logic of the grass-roots government and the rural logic takes place. In the case of limited personnel and no special work subsidies (only land supplement fund, but lack of subsidies for staff), grass-roots village committees are very limited in their enthusiasm for work and the space they can achieve. Therefore, the practice of reiterating old accounts and putting aside problems appears. Because in our survey, met a lot of family problems caused by land, such as population flow which is this one of the important goals of equaling, namely, redefine because family development, population flow and the change of land ownership problems, but in our interview survey found that most of these problems without coordination or invalid coordination can only be shelved. Land ownership relations involve a wide range of issues, especially when it comes to the lack of historical references or conflicts within families, and there is no basis for relevant provisions. Even though many land arbitration tribunals have been established for land right confirmation disputes, this arbitration tribunal still stays at the stage of "rule of man" rather than "rule of law".

\section{Reconstruction of Rural Land Right Confirmation under the Movement Governance}

1) The imbalance of land tenure confirmation

a) Inefficiency and buck-passing in multi-department cooperation

Although the local government has set up leading groups and stipulated the responsibilities of various departments, the actual operation involves the cooperation of county, township and village committees and more than a dozen departments. The cooperation of multiple departments and the large number of responsible parties lead to the absence of departments that really take responsibility and the serious phenomenon of responsibility buck-passing.

At the same time, because of the temporary movement of governance, many departments and village committees lack of human resources and financial resources to carry out this work, resulting in low work efficiency. At the same time, there are no perfect laws and regulations and clear fixed patterns. The rework phenomenon appears in the coordination, which increases the administrative management cost.

b) Insufficient local implementation and low participation of farmers 
Through interviews and surveys, we find that farmers have a low participation in the whole process and are basically in a passive state. The intention is to safeguard the vital interests of farmers, but fewer than $50 \%$ of farmers truly understand the policy intention in our survey. The lack of publicity at the grassroots level is the direct cause of this phenomenon. In the implementation process, many places took out the old cadastre and re-signed it to simplify or even omit the intermediate process. Although relevant departments have carried out propaganda work in rural areas, the effect is not ideal. As a result, many farmers do not have a deep understanding of this policy, and many problems are half-baked. It is not clear exactly what the policy will do for them, though they generally think their rights have not been harmed.

c) The shelving of disputes has not really solved people's concerns

In order to solve the problems existing in the governance object in a short time, local governments will encounter interference and obstacles from all kinds of vested interests under the incentive of political achievements and the pressure from the grass-roots level to complete the task. In order to achieve the goal and ensure the smooth implementation of the governance process, the governance body must use administrative orders and enforcement of compulsory means to carry out a strong strike against various ACTS interfering with governance. Of course, this is to ensure the implementation of various measures in the governance process, but due to the problem of unclear land ownership boundary address in the process of land right confirmation, due to various reasons for a long period of time, the land ownership boundary address is not clear. If it is implemented forcefully at this time, it is likely to be mishandled, which will affect the progress and quality of the land right confirmation work and even stimulate the contradiction between the masses and the government.

d) Lack of return visit supervision mechanism and limited implementation of right confirmation results

In our investigation, we found that although the subjects at all levels have stipulated the corresponding inspection and random inspection mechanism, there is no real supervision on the results of the confirmation of rights. For most villagers, even if the number on the land certificate changes, the number of land remains unchanged. For the occupation of rural public land, although the survey warned against this behavior, the unlicensed occupation of land after work has not changed.

e) Digital platform construction lags behind

In our interviews with grassroots government staff, we found that although the land right confirmation has been completed under the requirements of the central government, the cadastral information has not been updated timely. As an important goal of this right confirmation work, the establishment of a digital platform for cadastral management will gradually promote the development of e-government. Cadastral information has not been reported in time, and local information platforms are mostly under construction, which are not in sync with 
the right confirmation work, which lays hidden dangers for the future cadastral information management, and may also cause data loss in this process and damage the achievements of land right confirmation.

In the process of rural land right confirmation, every step and every subject has imbalance and contradiction. The central government, as the entrusting party, carried out the project to clarify rural land ownership and improved a modern and clear cadastral management system. However, this method has some natural defects, such as short-term governance time, temporary task and repeatability. Campaign governance can easily encourage arbitrary law enforcement, thus affecting the image of the government. Faced with such a huge task, the local government, as the contractor, is often in shortage of personnel and funds. In addition, due to the lack of perfect legal norms and express provisions, many responsible departments have evading, making rework frequent in coordination. As the main agent, the most convenient way is to simplify and omit the intermediate process. On the one hand, we actively cooperate with the third-party surveying and mapping company to update the cadastral data according to the measurement results; on the other hand, we take out the previous files and re-sign with the villagers. As for the target of the policy, farmers are often in a very passive position. They have little knowledge of the policy and do not understand its benefits and implications.

In terms of the relationship between several subjects, as a third party technology company, on the one hand, it collaborates with the government to build a digital platform, and on the other hand, it organizes field survey. The main problem is that the digital construction lags behind the actual demand. The relationship between the government and village committees and villagers is two-sided. First, in order to avoid conflicts and solve problems in a short time, the government may shelve disputes to ensure reasonable governance, but if conflicts are not properly solved for a long time, they will become more and more serious and even become larger mass conflicts. On the other hand, it is people's return visit and supervision. In the inspection and random inspection mechanism stipulated by subjects at all levels, there is no real mechanism corresponding to the supervision of the results of right confirmation. Most villagers neither understand this policy, nor can they complain about the phenomenon of land occupation, so they cannot effectively supervise the work of right confirmation.

2) Suggestions on problems existing in the implementation of the work

a) Improve the regulations on dispute settlement, and allow arbitration institutions to move from "rule of man" to "rule of law"

There are a lot of disputes in the land right confirmation work. This is because the comprehensive experience of the whole country has been used to introduce a perfect dispute settlement method, so that the land right confirmation arbitration institutions can be relied on, rather than just relying on personal judgment to deal with problems. 
b) Strictly implement the supervision and inspection mechanism, and truly implement the results of the confirmation of power

The supervision and evaluation of the effect of policy implementation is a weak item in China's policy agenda, and the neglect of the evaluation of the effect of policy implementation is also a common phenomenon in the land right confirmation work. Therefore, the land right confirmation work is by no means the end point at the present stage, and the supervision and implementation work at the later stage has a long way to go.

c) Expand channels of publicity and feedback, listen to people's concerns and solve their concerns

Feedback is an important part of land right confirmation. We should broaden the channels of feedback and actively listen to the opinions of the masses. Based on the opinions of the masses, we will summarize and rectify the work in the later stage so as to adopt more convenient land right confirmation measures that are more conducive to the peasants in the future work. In the process of policy implementation, the propaganda should be strengthened and the policy interpretation should be carried out in an appropriate form, so that farmers can better grasp the policy and protect their own rights and interests.

Although movement governance has problems such as department cooperation and inadequate planning, its direct effectiveness in solving some specific problems has laid an important position in social governance. From the perspective of the relationship between the entrusting party and the contractor, we can only improve the relevant rules and regulations step by step, avoid arbitrary law enforcement and irregularities, clarify the responsibilities of all parts, rather than absent, and strive to maintain the credibility of the government. As the agent of the village committee to do is to further do a good job of communication work, strengthen the propaganda, put every policy into effect, deal with the dispute between the masses. Villagers should also raise their awareness of active participation.

The key to solving the problem is between local governments and farmers. To better implement the work, the government should first broaden the channels of public opinion response, collect rural opinions from the top down, and take solving people's concerns as the starting point. At the same time, it should also strengthen propaganda and do a good job in policy interpretation. In addition, supervision and evaluation are weak items in China's policy agenda, and the government should improve the return visit and supervision institutions.

3) How can we achieve good governance at the grassroots level?

Under sports governance, there will inevitably be insufficient supporting facilities at all levels, which will adversely affect the quality of policy implementation. It is not uncommon for people at the grassroots level to put problems on hold. This has seriously shaken the legitimacy and authority of the ruling position of the party and government at the grassroots level, and seriously damaged the image of the party and government. 
How to achieve good governance at the grassroots level? The author believes that the most important thing is to give full play to the role of top-level design, attach importance to long-term planning, and take grassroots issues, especially the governance of "three rural issues", into China's five-year plan, carry out work planning from top to bottom, achieve orderly and prepared governance, and use perfect system to deal with potential contradictions.

\section{Conflicts of Interest}

The author declares no conflicts of interest regarding the publication of this paper.

\section{References}

[1] Yu, J. and Shi, F. (2012) Several Important Issues on the Current Rural Land Right Confirmation in China. Southeast Academic Journal, No. 4, 4-11.

[2] Yu, J. (2005) Land Issue Has Become the Focus of Peasants' Rights Protection Protests. Survey World, No. 3, 22-23.

[3] Tan, S. (2008) Concept, Characteristics and Trigger Factors of Land Conflict in China. China Land Science, 22, 4-11.

[4] Li, H., Tan, S. and You, H. (2006) Contemporary Land Conflicts in China and Their Root Causes. New Horizons from Tianfu, No. 6, 60-63.

[5] Tang Emperor Chicken (2007) Normal Society and Movement Governance-Research on "Strike Hard" Policy in China's Social Security Governance. Open Era, No. 3, 115-129.

[6] Yan, W. and Li, S. (2018) Sport Governance in the Context of National Governance Modernization: Internal Logic, Conflict and Reflection Beyond. Journal of Tianjin University of Administration, No. 5, 54-63.

[7] Ouyang (2014) Discuss Basic-Level Sport Management, Hold the Discussion Such as Zhou Xueguang Concurrently. Open Era, No. 6, 180-190. 